\title{
Radiología neonatal
}

\author{
Tamara G. Kreindel ${ }^{1}$ \\ ${ }^{1}$ Encargada del Área de Radiología Pediátrica del Servicio de \\ Diagnóstico por Imágenes del Hospital Italiano de Buenos Aires, \\ Ciudad Autónoma de Buenos Aires, Argentina.
}

Rev Argent Radiol 2020;84:43-44.

\section{Eloy López Marure \\ Radiología Neonatal \\ Ediciones Journal, Buenos Aires, Argentina, 2019. (ISBN:9789874922106)}

Se trata de la primera edición de Radiología Neonatal. El autor es pediatra y radiólogo pediatra, profesor de Radiología y Pediatría del Hospital Civil Dr. Juan I Menchaca y Unidad de Patología Clínica, Guadalajara, México. Su formación se refleja en los contenidos del libro, donde ofrece un enfoque clínico de cada patología, para luego hacer referencia al aspecto radiológico en el manejo del paciente neonatal. El libro consta de un poco más de 350 páginas divididas en cinco capítulos: Sistema Nervioso Central y Médula Espinal, Tórax, Abdomen, Sistema Renal, Vías Urinarias y Aparato

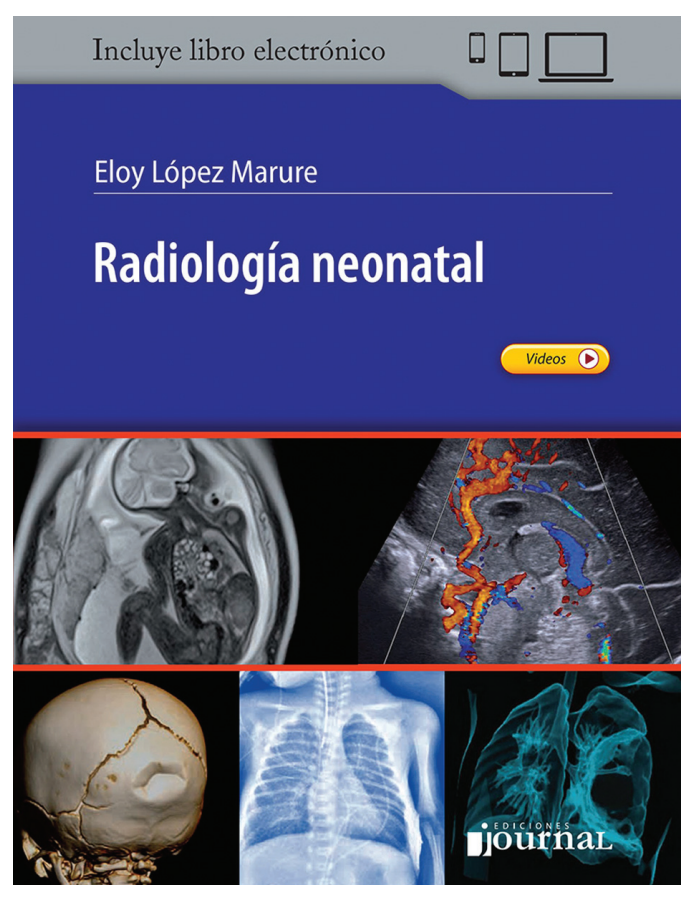

DOI https://doi.org/ $10.1055 / \mathrm{s}-0040-1708467$. ISSN 1852-9992.
Address for correspondence Tamara G. Kreindel, (e-mail: tamara.kreindel@hospitalitaliano.org.ar).

Genital, y Sistema Esquelético y Malformaciones de Tejidos Blandos.

El libro está escrito de una forma detallada y a la vez fácilmente entendible, tanto para radiólogos en formación como para radiólogos generalistas y médicos especializados en radiología pediátrica. También puede ser de utilidad para neonatólogos que deseen profundizar sus conocimientos radiológicos.

Además de la información clínica mencionada, se describen de forma completa y actualizada los métodos disponibles para el estudio de cada patología, y se brinda orientación acerca de la elección y orden de utilización de cada uno de ellos. Se describen, además, las técnicas imagenológicas, los hallazgos normales y gran parte de las patologías que pueden encontrarse en la práctica cotidiana en el tratamiento de pacientes neonatales.

Es de destacar la excelente calidad de las imágenes. Se incluyen fotos clínicas, quirúrgicas y por supuesto radiológicas. Esas últimas muestran, en múltiples ocasiones, más de un método para la misma patología y han sido adecuadamente seleccionadas, ya que ejemplifican con precisión los tópicos tratados. Ofrece, además, la posibilidad de acceder a videos en el formato electrónico del libro.

El capítulo de Sistema Nervioso Central y Médula Espinal comprende aproximadamente un tercio del libro. La totalidad de las patologías desarrolladas brindan información de los diferentes métodos de imágenes, con sus correspondientes ilustraciones. Aborda desde las variantes normales, malformaciones, patología del paciente nacido pretérmino, infecciones, tumores, trauma y enfermedades de la médula espinal, incluyendo las patologías más y menos frecuentes.

El capítulo de Tórax cuenta con una introducción de los aspectos clínicos del sistema respiratorio del paciente neonatal, y hace referencia a la embriología y anatomía. Presenta un orden interesante y cómodo de leer. Hace hincapié en las particularidades de los estudios radiográficos en el paciente neonatal, detallando la técnica y los cuidados a tener presentes, así como conceptos de radioprotección. Describe la

\section{Copyright ( $)$ 2020, Sociedad Argentina License terms de Radiología. Publicado por Thieme Revinter Publicações Ltda., Rio de} Janeiro, Brazil. Todos los derechos reservados. 
visualización de elementos externos, de suma importancia en esos pacientes, así como las causas médicas y quirúrgicas de las enfermedades respiratorias en el paciente recién nacido, abarcando un interesante espectro de patologías. Da cuenta, también, de la visualización del timo en el paciente neonatal, elemento útil, ya que se diferencia de lo observado en otras franjas etarias. Al final, detalla los diferentes métodos aplicables al tórax, incluyendo la radiografía, ultrasonido, tomografía computada y resonancia magnética.

El capítulo de Abdomen presenta abundante información gráfica quirúrgica que lo hace muy interesante, complementando los estudios de imagen. Detalla la patología malformativa, tumoral, enterocolitis necrotizane y patología quirúrgica aguda. El final del capítulo se refiere a la patología hepática, en especial al síndrome coledociano. Brinda información acerca de los diferentes métodos de imagen, dando importancia a la radiología convencional, ecografía y estudios contrastados.

El capítulo de Sistema Renal, Vías Urinarias y Aparato Genital comienza con una descripción de los diferentes métodos de estudio. Detalla luego las patologías de las vías urinarias, infecciones y anomalías del parénquima renal. Luego repasa de forma breve las patologías de los sistemas genitales.

El capítulo de Sistema Esquelético y Malformaciones de Tejidos Blandos es breve y comienza con la descripción de enfermedades óseas, que incluyen patologías comunes como la displasia del desarrollo de la cadera, y otras menos frecuentes como las displasias óseas neonatales. Luego hace referencia a patologías cervicales, anomalías vasculares y algunas enfermedades cutáneas.

El libro provee, al final de cada capítulo, una bibliografía muy completa, amplia y actualizada. Es un libro de muy fácil lectura, que permite actualizar los conocimientos imagenológicos de los hallazgos normales y patológicos del paciente neonatal. La compra del libro permite, a su vez, el acceso a la edición digital, que cuenta con videos ilustrativos.

Recomiendo la lectura de Radiología Neonatal a aquellos médicos interesados en conocer, repasar o avanzar en la valoración de la patología del paciente neonatal de forma rápida y actualizada. 